\title{
First records on non-biting midges (Diptera: Chironomidae) from the Rovno amber
}

\author{
Первые находки комаров-звонцов (Diptera: Chironomidae) \\ из ровенского янтаря
}

\author{
N.I Zelentsov ${ }^{1}$, V.A. Baranov ${ }^{2}$, E.E Perkovsky ${ }^{3} \&$ N.A. Shobanov ${ }^{1}$
}

Н.И. Зеленџов ${ }^{1}$, В.А. Баранов ${ }^{2}$ Е.Э. Перковский ${ }^{3}$, Н.А. Шобанов ${ }^{1}$

\footnotetext{
${ }^{1}$ Institute for Biology of Inland Waters, Russian Academy of Science, Borok, Yaroslavl oblast, 152742, Russia.

1 Учреждение российской академии наук Институт биологии внутренних вод им. И.Д. Папанина РАН, Борок, Ярославская область, 152742, Россия. E-mail: shobanov@ibiw.yaroslavl.ru

${ }^{2}$ V.N. Karazin Kharkov National University, Department of zoology and animal ecology, 4 Svoboda Sq., 61077 Kharkiv, Ukraine.

${ }^{2}$ Харьковский Национальный Университет им. В.Н. Каразина, Кафедра зоологии и экологии животных, Площадь Свободы 4 , 61077, Харьков, Украина. E-mail: baranowiktor@gmail.com

${ }^{3}$ Schmalhausen Institute of Zoology, National Academy of Sciences of Ukraine, Bogdana Khmel'nitskogo st. 15, Kiev 01601, Ukraine.

3 Институт зоологии им. И.И. Шмальгаузена Национальной академии наук Украины, ул. Богдана Хмельницкого 15, Киев 01601, Украина. E-mail: perkovsky@fromru.com
}

KEY WORDS: Chironomidae, terrestrial larvae, Rovno amber, Ukraine, Smittia, Orthocladiinae, subfamilies composition.

КЛЮЧЕВЫЕ СЛОВА: Chironomidae, наземная личинка, ровенский янтарь, Украина, Smittia, Orthocladiinae, соотношение подсемейств.

ABSTRACT: First records of non-biting midges (Diptera: Chironomidae) in the Rovno amber are provided. 12 extant genera, three of which are known from the Baltic amber, are recorded. Representatives of the five genera were recorded in the fossil state for the first time: Macropelopia, Brillia, Limnophyes, Hydrosmittia and Cladopelma; Orthocladius recorded in the first time for the fossil resins.

Rovno amber fauna of chironomids differs from the Baltic one by extremely high percent of the midges with terrestrial larva. Smittia, Hydrosmittia, Metriocnemus constitute about $40 \%$ of all chironomids, determined to the generic level.

PЕЗЮМЕ: Приводятся первые данные о представителях семейства Chironomidae (Diptera) из ровенского янтаря. Обнаружены представители 12 современных родов, три из которых были известны из балтийского янтаря. Впервые выявлены в ископаемом состоянии представители родов Macropelopia, Brillia, Limnophyes, Hydrosmittia u Cladopelma; Orthocladius впервые указан для ископаемых смол. В отличие от балтийского янтаря, в ровенском янтаре обнаружен необычно высокий процент видов Chironomidae с наземной личинкой; Smittia , Hydrosmittia, Metriocnemus составляют 40\% от всех хирономид, определённых до рода.

\section{Introduction}

Chironomidae are common inhabitants of most aquatic, semiaquatic and some terrestrial habitats, they often dominate aquatic insect communities in both abundance and species richness. Species are known to occur in all continents, including Antarctica, and most major oceanic islands that have been investigated [Ferrington, 2007]. Chironomids (non-biting midges) are frequently used as bioindicators in classifying and monitoring different freshwater environments [Ferrington, 2007].

Late Eocene Rovno amber represents a southern coeval analogue of the famous Baltic amber collected in the northwest of Ukraine [Perkovsky et al., 2003; Perkovsky et al., 2010a]. The general scarcity of amphibiotic insects appears typical of the Rovno amber [Perkovsky et al., 2010a]. It is clearly seen from the comparatively low representation of chironomids [Perkovsky et al., 2003, 2010] in the Rovno assemblage combined with a high participation of those having terrestrial larvae [Perkovsky et al., 2003].

\section{Material and methods}

The material was collected in Klesov and Dubrovitsa in 1999-2000 [Perkovsky et al., 2003] and was placed in the SIZK collection (Schmalhausen Institute of Zoology, 
Kiev) in 2000-2001. The samples have been cutted to thin pieces and polished at the factory "Ukramber" (Rovno) by A. P. Vlaskin. The material was preliminary identified by N.I. Zelentsov and N.A. Shobanov. Terminology in chironomids morphology after Sæther [1980].

\section{Results}

Following is the list of records of genera identified in the Rovno amber, with short ecological characteristic of each genus.

\section{Subfamily Tanypodinae Zavrel, 1916}

Genus Ablabesmyia Johannsen, 1905 Ablabesmyia sp.

MATERIAL. SIZK:UA-98, o7.

TAXONOMIC POSITION. This specimen belongs to Ablabesmyia due to the following combination of characters: Males of Ablabesmyia are distinctly pigmented and could be easily recognized by leg bands, cochleariform megaseta. Other important characters, that separate Ablabesmyia from the other Tanypodinae (shape of the superior volsella of the hypopygium, shape of the tibial combs) are not clearly seen.

ECOLOGY AND DISTRIBUTION. The genus occurs The genus occurs worldwide, larvae of Ablabesmyia inhabit a wide variety of standing and flowing waters [Murray \& Fittkau, 1989].

FOSSIL RECORDS. Ablabesmyia eocenica Doitteau \& Nel, 2007 from the earliest Eocene Oise amber, A. electrohispaniolana Grund, 2005 from the Miocene Dominican amber.

Genus Macropelopia Thienemann, 1916

$$
\text { Macropelopia sp. }
$$

MATERIAL. SIZK:UA-132, $0^{7}$.

TAXONOMIC POSITION. This specimen runs to Macropelopia in the key provided by Murray \& Fittkau [1989] due to the following combination of characters: FCu sessile, $\mathrm{Ta}_{4}$ cylindrical, costa produced beyond $\mathrm{R}_{4+5}$, at the length of $\mathrm{RM}$, tibial spurs flattened, tibiae uncoloured, inferior volsella present. Other important characters are lacking in this specimen (setation of anteropronotum, setation and absence/ presence of mesonotal tubercle, shape of eyes and antenna) its position in Macropelopia has to be regarded as tentative (some resemblance with Alotanypus Roback, 1971, Bethbilbeckia Fittkau \& Murray, 1968, Brundiniella Roback, 1978, Derotanypus Roback, 1971 or Fittkauimyia Karunakaran, 1969 could be postulated, but the general shape of the genitalia indicates a closer relationship with Macropelopia).

ECOLOGY AND DISTRIBUTION. The genus occurs worldwide, at least 11 species are known from the Palearctic, and at least 5 are recorded from the Nearctic. Larvae of this genus are reported living in a wide range of freshwater habitats, but can be regarded as cold-stenothermic species [Murray \& Fittkau, 1989].

FOSSIL RECORDS. No pre-Pleistocene records [Evenhuis, 1994].

Subfamily Orthocladiinae Edwards, 1929

Genus Brillia Kieffer, 1913

$$
\text { Brillia sp. }
$$

MATERIAL. SIZK:UA-31, O?

TAXONOMIC POSITION. This specimen runs to Brillia in the key provided by Cranston et al. [1989: 179] due to the following combination of characters: bare eyes with long, parallel-side extension; fringed squama and wing covered with macrotrichia; long, digitiform SVo and IVo; bifid gonostylus without megasetae; and absence of anal point. It fits in the Brilla modesta (Meigen, 1830) group due to the shape of the main branches of the gonostylus, however this specimen have a rather unusual position of $\mathrm{FCu}$ (clearly distal to RM).

ECOLOGY AND DISTRIBUTION. The genus is known from the Holarctic and Oriental regions. At least 9 species are known from the Palearctic and Oriental regions, and at least 5 are recorded from the Nearctic. Larvae reported living in a wide range of freshwater habitats, often associated with allochtonous plant material (larvae of $B$. longifurca Kieffer, 1921 group mine wood, and larvae of $B$. modesta group feed on decayed leaves [see Cranston et al., 1989: 179]).

FOSSIL RECORDS. No pre-Pleistocene records [Evenhuis, 1994].

Genus Cricotopus v.d. Wulp, 1874

$$
\text { Cricotopus sp. }
$$

MATERIAL. SIZK: UA- 404, ơ; UA-92, $0^{7}$.

TAXONOMIC POSITION. This specimen UA-404) runs to Cricotopus in the key provided by Cranston et al. (1989) due to the following combination of characters: pubescent eyes and decumbent dorsocentrals. Because of the missing hypopygium, we could not placed this species in Cricotopus with certain. It may also belongs to Halocladius Hirvenoja 1973 or Paracladius Hirvenoja 1973 [Dr. Humberto Mendes, personal communication, 2011].

ECOLOGY AND DISTRIBUTION. The genus occurs worldwide, at least 60 are species found in the Palearctic and 40 in the Nearctic regions [Cranston et al., 1989: 189]. Larvae live in a wide range of freshwater, saline and madicolous habitats. Accurate identification of the larval habitat without determination of the subgenera is nearly impossible.

FOSSIL RECORDS. Twenty-four species from the Baltic amber, all recorded as nomena dubium in Wichard et al., 2009.

Genus Heterotrissocladius Spark, 1923

Heterotrissocladius sp. near paleolacustris Seredszus, 2007

MATERIAL. SIZK: UA-391, O'; UA-408, O'.

TAXONOMIC POSITION. One of our specimens UA391) runs to Heterotrissocladius in the key provided by Cranston et al. [1989: 202] due to the following combination of characters: bare eyes, wing with macrotrichia, anteropronotal lobes divided, Costa not extended; $\mathrm{R}_{4+5}$ distal to $\mathrm{M}_{3+4}$ The second specimen has no considerable differences from it. The specimens appears close to the Heterotrissocladius paleolacustris Seredszus, 2007 [Seredszus \& Wichard, 2007] by the all characters, but cannot be confirmed as such because of some important details of the hypopygium can not be verified.

ECOLOGY AND DISTRIBUTION. The genus is Holarctic with 16 known species included. There are however some unnamed additional records from Ecuador [Cranston et al., 1989]. The immature stages of the Heterotrissocladius are found from the littoral to profundal of oligotrophic and ultraoligotrophic lakes, some species may also occur in rivers and springs.

FOSSIL RECORDS. H. paleolacustris Seredszus, 2007 [Seredszus \& Wichard, 2007], is recorded from the Late Eocene Baltic amber. 
Genus Hydrosmittia Sæther \& Ferrington, 2011 Hydrosmittia sp.

MATERIAL. SIZK: UA-89, $0^{7}$; UA-311, $0^{7}$

TAXONOMIC POSITION. One of our specimens, UA-89, key to Hydrosmittia in Ferrington \& Sæther [2011] due to the following combination of characters: bare eyes, wings and squama, midscutum without additional tubercle, hump or microtrichial tuft; non-extended, non-protruding eyes; palpi not reduced; median antepronotal lobe well developed, supraalars are absent; anal lobe of the wing well developed and projecting; costa not extended, $\mathrm{R}_{4+5}$ ending above to end of the $\mathrm{M}_{3+4}, \mathrm{Cu}_{1}$ sinuous; superior and median volsella absent; male gonostylus simple. The second specimen has no considerable differences from this diagnosis, but the hypopygium is not clearly seen.

ECOLOGY AND DISTRIBUTION. The genus occurs worldwide, 18 species are recognised. Immature stages of the majority of species are aquatic, probably living in algal growths on stones as most other species of the Pseudosmittia-group.

FOSSIL RECORDS. No pre-Pleistocene records [Evenhuis, 1994].
Genus Metriocnemus v. d. Wulp, 1874 Metriocnemus sp.

MATERIAL. SIZK: UA-105, ○7; UA-162, ; UA-164, ; UA169,, ; UA-170,, ; UA-312, + .

TAXONOMIC POSITION. All specimens key to Metriocnemus in Cranston et al. [1989: 212] due to the following combination of characters: bare eyes, numerous setae on squama, wings with macrotrichia, $\mathrm{Cu}_{1}$ straight, body with numerous setae, on the some specimens UA-105) other important diagnostic characters are clearly seen - presence of the tarsal pseudospurs, minute pulvilli.

ECOLOGY AND DISTRIBUTION. Metirocnemus occurs worldwide, 60 species are Holarctic. The immature stages can be found in mosses, phytotelmata, springs and streams, one species is known from lakes, at least 2 could be hygropetric [Cranston et al., 1989].

FOSSIL RECORDS. Metriocnemus cretatus Boesel, 1937 is recorded from the Upper Cretaceous Canadian amber [Evenhuis, 1994]. Many important characters (shape and number of acrostichals and dorsocentrals setae, bare/pubes-

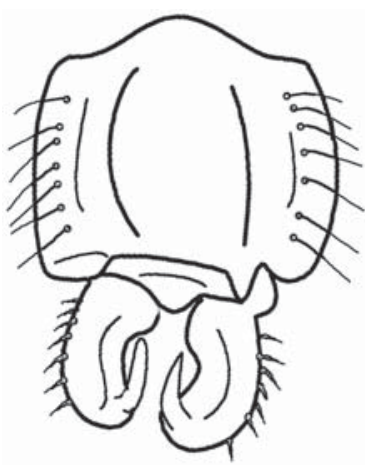

1
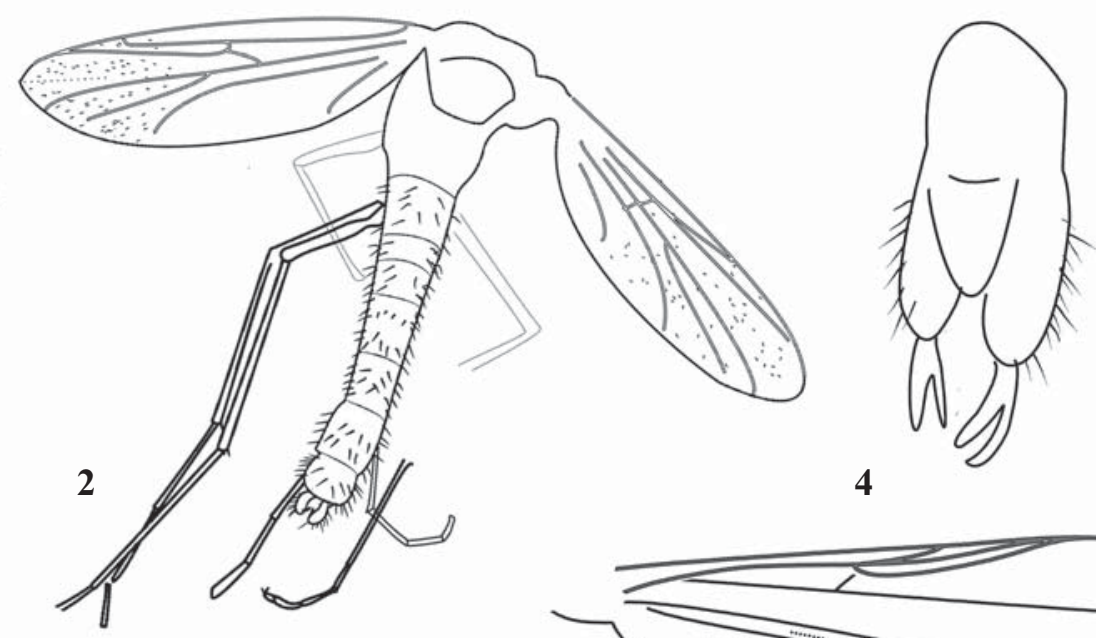

4

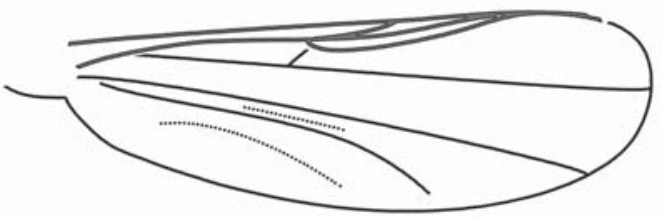

5
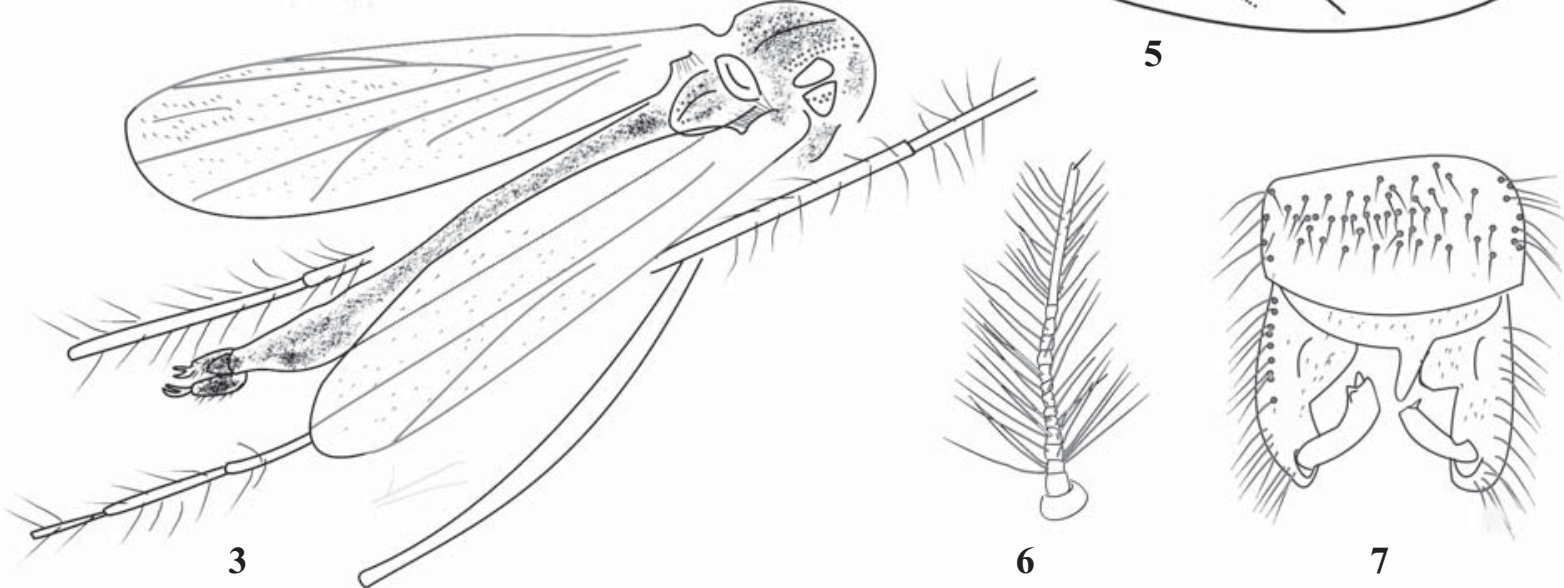

Figs 1-7. Male imagines: 1-2 - Macropelopia sp. (UA-132); 3-4 - Brillia sp. (UA-31); 5-7 — Smittia sp. (UA-201); 1, 4, 7 -male hypopygium; $2-3$ - male habitus; 5 - wing; 6 - male antenna.

Рис. 1-7. Имаго, самцы: 1-2 - Macropelopia sp. (UA-132); 3-4 - Brillia sp.( UA-31); 5-7 — Smittia sp. (UA-201); 1, 4, 7 гипопигий самца; 2-3 - габитус самца; 5 - крыло; 7 - антенна самца. 
cent eyes) are not described in Boesel [1937], thats way placement of this cretaceous species in Metriocnemus is dubious. It is the first Eocene record.

\section{Genus Limnophyes Eaton, 1875 Limnophyes sp.}

MATERIAL. SIZK: UA- $88,+$; UA- $94,+$; UA- $99,+9,0^{7}$; UA-

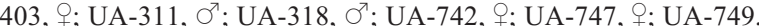
; UA-754, + ; UA-795, 9 ; UA-805, + ; UA-807, + ; UA-809,, ; UA-

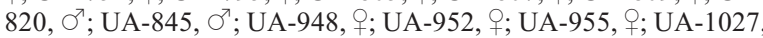
2 , $50^{7}$; , UA-1037, $30^{7}$ \& UA-1038, $O^{7}$ (in syninclusion with 2 fragments of orthoclad males)

TAXONOMIC POSITION. All specimens of Limnophyes were easily identifiable based on scallpelate humerals, bare eyes and wing. The other diagnostic characters in the key provided by Cranston et al. [1989] were seen only in some specimens. The dorsal anteropronotals and pleural setae are present [Cranston et al., 1989].

ECOLOGY AND DISTRIBUTION. The genus occurs worldwide, about 40 species are known from the Holarctic. Limnophyes is a eurytopic genus, larvae are found in most types of the terrestrial, semiterrestrial and aquatic habitats [Cranston et al., 1989].

FOSSIL RECORDS. No pre-Pleistocene records [Evenhuis, 1994].

Genus Orthocladius v.d. Wulp, 1874

Orthocladius sp.

MATERIAL. SIZK: UA-826, O'; UA-1010, O'; UA-1020, $0^{7}$

TAXONOMIC POSITION. These specimens key to $\mathrm{Or}$ thocladius in Cranston et al. [1989] due to the following
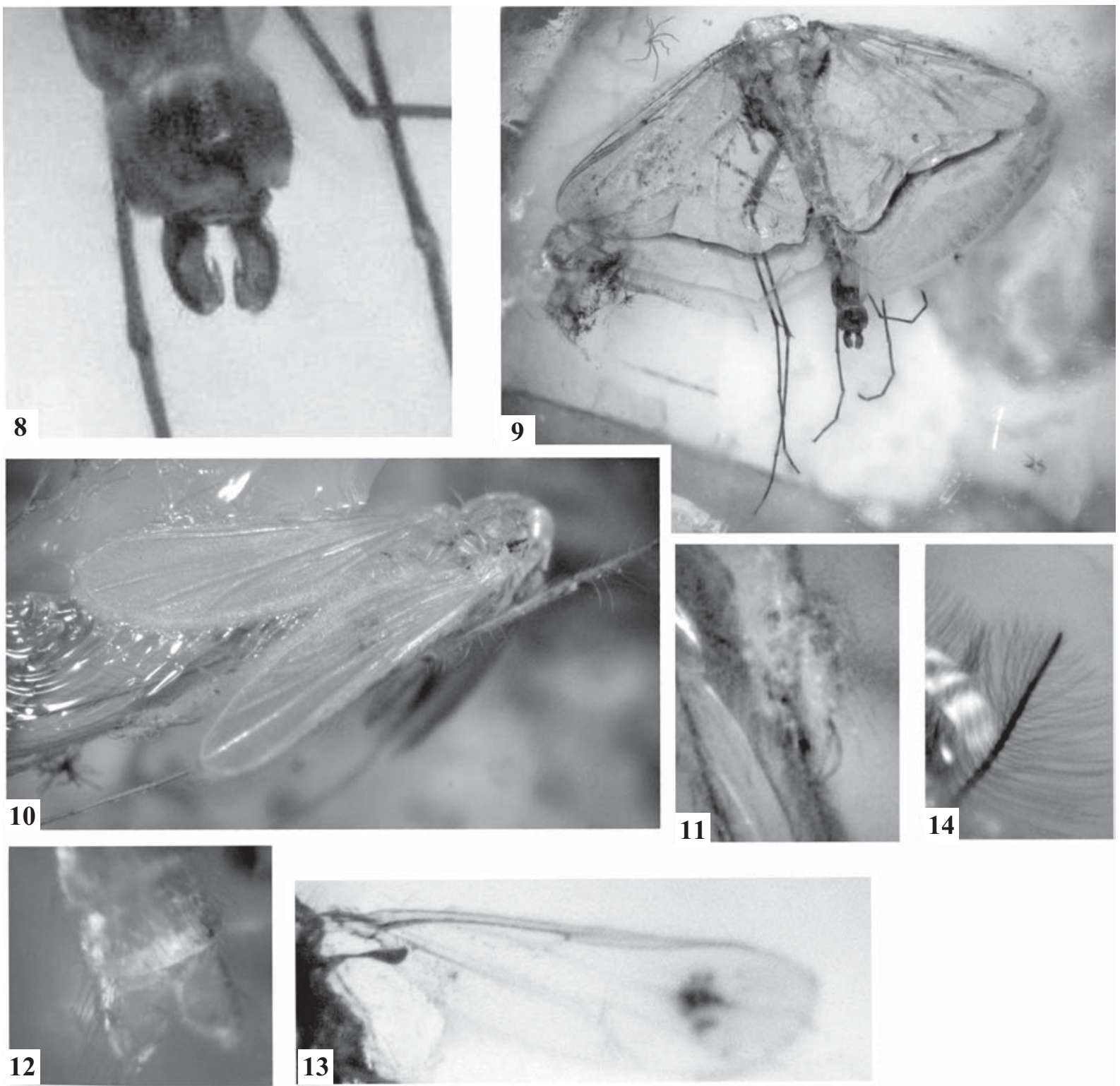

Figs 8-14. Male imagines: 8-9 - Macropelopia sp. (UA-132); 10-11 - Brillia sp. (UA-31); 12-14 - Smittia sp. (UA-201); 8, 1112 - male hypopygium; 9-10 - male habitus; 13 - wing; 14 - male antenna.

Рис. 8-14. Имаго, самцы: 8-9 — Macropelopia sp.(UA-132); 10-11 - Brillia sp.( UA-31); 12-14 — Smittia sp. (UA-201); 8, 1112 - гипопигий самца; 9-10 - габитус самца; 13 - крыло; 14 - антенна самца. 
combination of characters: anteropronotal lobes narrowed medially, and narrowly joined anterior to scutal projection, with a shallow median notch. The acrostichals begins anteriorly near the anteropronotum. The hypopygia of the three specimens were not able to be examined.

ECOLOGY AND DISTRIBUTION. Orthocladius is worldwide, about 100 species are described from the Holarctic region. Larvae of Orthocladius inhabit all types of flowing water [Cranston et al., 1989].

FOSSIL RECORDS. Orthocladius is recorded from Rott (Oligocene) [Evenhuis, 1994]. It is the first Eocene record.

Genus Parachaetocladius Wülker, 1959

\section{Parachaetocladius sp.}

MATERIAL. SIZK: UA-196, $20^{7}$; UA-197, $0^{7}$; UA-1325, $0^{7}$ (together with 2 other males).

TAXONOMIC POSITION. One of these specimens (UA-196) key to Parachaetocladius in Cranston et al. [1989] due to the following combination of characters: acrostichals lacking, wide-triangle anal point, pulvilli present, bare wing membrane, gonostylus with an outer heel, apical setae on antenna, $\mathrm{Cu}_{1}$ curved. The other three specimens have no considerable differences, but are quite badly preserved. They are easily separable from the closely related genus Parametriocnemus Goetghebeur, 1932 by the bare wings and gonostylus with the outer angle.

ECOLOGY AND DISTRIBUTION. Parachaetocladius abnobaeus (Wülker, 1959) and P. retezat Albu, 1972 are found in Europe, one species is described from the Nearctic, based on the larvae. Immature stages are found in the small springs, spring fed streams and small rivers.
FOSSIL RECORDS. One species, P. balticus Seredszus, 2007 [Seredszus \& Wichard, 2007], is recorded from the Late Eocene Baltic amber.

\section{Genus Smittia Holmgren, 1869}

\section{Smittia sp.}

MATERIAL. SIZK: UA-95, О'; UA-101, $\sigma^{7}$; UA-104, $\bigcirc^{7}$;. UA-

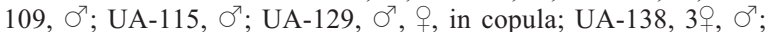
UA-147, , + UA-156, О' 201, $\odot^{7}$; UA-289, $\bigcirc^{7},+$, in copula; UA-316, $20^{7},+$; UA-830, $\odot^{7}$; UA$1325 \mathrm{a}, \mathrm{O}^{7}$

TAXONOMIC POSITION. Most of the specimens key to Smittia due to the following combination of characters: bare squama and wings, strong subapical setae on the tip of antenna, long anal point, and gonostylus with crista dorsalis. The others are not separated from them by considerable differences, but lack of some characters, listed above. The specimens from the Rovno amber seem close to the Smittia edwardsi Goetghebuer, 1932 - group, but can be separated from it by the strongly curved gonostylus and oval shaped inferior volsella [Cranston et al., 1989; Moller Pillot, 2009].

ECOLOGY AND DISTRIBUTION. Smittia is found worldwide [Cranston et al., 1989]. Larvae are mostly terrestrial.

FOSSIL RECORDS. Smittia veta Boesel, 1937 is known from the Upper Cretaceous Canadian amber [Evenhuis, 1994]. Main diagnostic characters (shape of male hypopigium, presence of the subapical setae on the last flagellomere, absence/ presence fringe at the squama) are not described or described poorly, except wing venation, that is really looks like a Smittia's wing. That's way, placement of this Cretaceous species in Smittia should be considered as dubious. It is the first Eocene record.

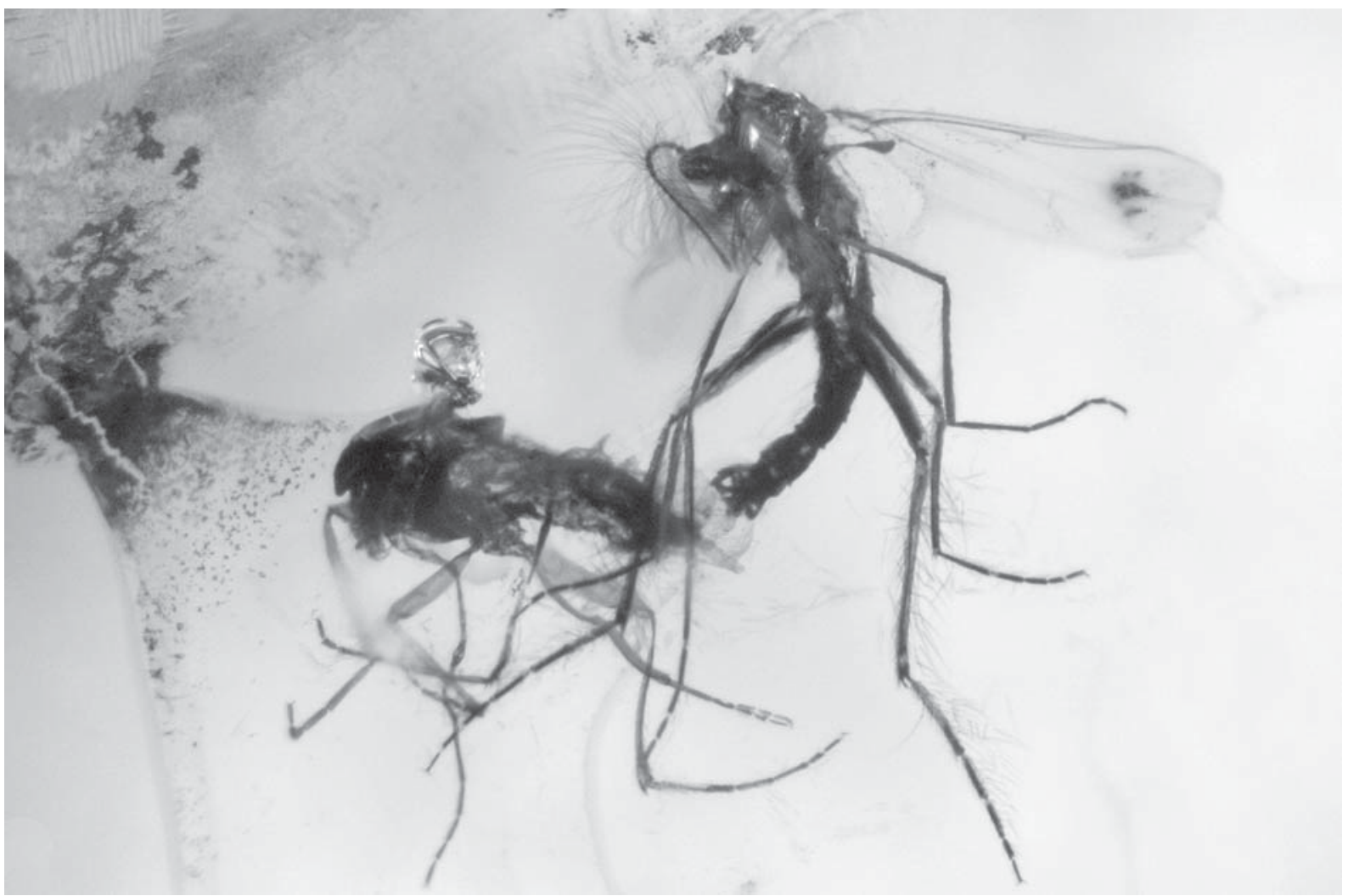

Fig. 15 A pair of Smittia sp. in copula (UA-129).

Рис. 15. Копулирующая пара Smittia sp. (UA-129). 
Orthocladiinae incertae sedis

Some specimens were identifiable only to subfamily level and cannot be assigned to genus.

MATERIAL. SIZK: 309: UA-9, UA-88, UA-91, UA-104, UA110, UA-114, UA-120, UA-134, UA-167, UA-168, UA-177, UA288, UA-291, UA-301(29), UA-310, UA-313, UA-317, UA-395, UA-401, UA-406, UA-413, UA-743, UA-745, UA-750, UA-757, UA-768, UA-773, UA-836, UA-952, UA-1026, UA-1035; $50^{7}$ : UA-100, UA-418, UA-1325b, UA-1038 (20 $\left.0^{7}\right)$; $\odot^{7}$, ㅇ: UA-936.

Subfamily Chironominae Macquart, 1828

Genus Cladopelma Kieffer, 1921

\section{Cladopelma sp.}

MATERIAL. SIZK: UA-188, $\mathrm{o}^{7}$

TAXONOMIC POSITION. This specimen runs to Cladopelma in Cranston et al. [1989] due to the following combination of characters: narrow and curved gonostylus, greatly reduced superior volsella and absence of the inferior volsella [Cranston et al., 1989]. We note, that the anal point of this species is relatively short and spatulated, thus it fits in the extant species $C$. virescens (Meigen, 1818).

ECOLOGY AND DISTRIBUTION. There are about 14 species in the Holarctic. Larvae occur in sandy and muddy substrates of both lakes and rivers [Cranston et al., 1989].

FOSSIL RECORDS: No pre-Pleistocene records [Evenhuis, 1994].

\section{Chironominae incertae sedis}

Some specimens were identifiable only to subfamily and cannot be assigned to genus.

MATERIAL. SIZK: UA-155, О' $0^{7}$ UA-195, $0^{7}$; UA-751, + ; UA761, O'; UA-113,, ; UA-1032, $0^{7}$, UA-1325b, $0^{7}$.

\section{Discussion}

Chironomidae are currently used for palaeoecological reconstructions in the Pleistocene and the Holocene. Their head capsules are frequent in lake sediments and identification at the genus or species level is possible [Cranston et al., 1989]. Different types of extant water bodies have different patterns of Chironomidae communities [Cranston et al., 1989, Sæther et al., 2000; Makarchenko \& Makarchenko, 2006]. Inferences are possible because the Pleistocene chironomids belong to extant species from the same areas (Europe and North America). Doitteau \&

NOTE. Rovno Amber - author's data; Baltic amber — Seredszus \& Wichard , 2007; Wichard et. al., 2009; Meuiner, 1904; Gilka, 2010, 2011. * - extinct genera; ** - species from those genera was described from the Baltic amber by Meunier \& Duisburg, and today recognized as nomen dubium [Wichard et. al., 2009]; *** — species from those genera was described from the Baltic amber by Meunier, and today recognized as nomen dubium except Tanytarsus serafini Gilka, 2010 and Tanytarsus fereci Gilka, 2011 [Gilka, 2010, 2011].

ПРИМЕЧАНИЕ: Ровенский янтарь - собственные данные; Балтийский янтарь - Seredszus \& Wichard, 2007; Wichard et. al., 2009; Meuiner, 1904; Gilka, 2010, 2011. *- вымершие роды; ** - виды из этих родов были описаны Менье и Дуйсбургом, и сегодня рассматриваются как nomen dubium [(Wichard et. al., 2009]; ***_- виды из этих родов были описаны Менье и Дуйсбургом, и сегодня рассматриваются как потеп dubium, кроме Tanytarsus serafini Gilka, 2010 \& Tanytarsus fereci Gilka, 2011 [Gilka, 2010, 2011].
Table 1. Diversity e of midges genera are found in Rovno and Baltic amber.

Таблица 1.Роды комаров-звонцов, найденных в ровенском и балтийском янтаре.

\begin{tabular}{|c|c|c|}
\hline Chironomidae genera & $\begin{array}{l}\text { Rovno } \\
\text { Amber }\end{array}$ & $\begin{array}{l}\text { Baltic } \\
\text { amber }\end{array}$ \\
\hline \begin{tabular}{|l|} 
Podonominae \\
\end{tabular} & - & + \\
\hline Lasiodiamesa & - & + \\
\hline Paraboreochlus & - & + \\
\hline Tanypodinae & + & + \\
\hline Ablabesmyia & + & - \\
\hline Apsectrotanypus & - & + \\
\hline Coelotanypus & - & + \\
\hline Macropelopia & + & - \\
\hline Palaeotanypus & - & + \\
\hline Tanypus & - & + \\
\hline Buchonomyiinae & - & + \\
\hline Buchonomyia & - & + \\
\hline Prodiamesinae & - & + \\
\hline Prodiamesa & - & + \\
\hline Orthocladiinae & + & + \\
\hline Acutiforcipia & - & + \\
\hline Brillia & + & - \\
\hline Bryophaenocladius & - & + \\
\hline Chaetocladius & - & + \\
\hline Camptocladius $^{*}$ & - & + \\
\hline Cricotopus & + & + \\
\hline Eurycnemus & - & + \\
\hline Flexicrus" & - & + \\
\hline Heterotrissocladius & + & + \\
\hline Hydrobaenus & - & + \\
\hline Hydrosmittia & + & - \\
\hline Krenosmittia & - & + \\
\hline Limnophyes & + & - \\
\hline Metriocnemus & + & - \\
\hline Orthocladius & + & - \\
\hline Parachaetocladius & + & + \\
\hline Parametriocnemus & - & + \\
\hline Paraphaenocladius & - & + \\
\hline Psectrocladius & - & + \\
\hline Pseudorthocladius & - & + \\
\hline Rheosmittia & - & + \\
\hline Smittia & + & - \\
\hline Thienemannia & - & + \\
\hline Tokyobrillia & - & + \\
\hline Zalutschia & - & + \\
\hline Chironominae & + & + \\
\hline Chironomus $^{*}$ & - & + \\
\hline Cladopelma & + & - \\
\hline Cricotopiella & - & + \\
\hline Phaenopsectra & - & + \\
\hline Stempellina & - & + \\
\hline Stempellinella & - & + \\
\hline Sendelia ${ }^{* *}$ & - & + \\
\hline Tanytarsus & - & + \\
\hline Number of subfamilies/genera & $3 / 12$ & $6 / 34$ \\
\hline $\begin{array}{l}\text { Subfamilies/genera found in both } \\
\text { Lagerstättes }\end{array}$ & \multicolumn{2}{|c|}{$3 / 3$} \\
\hline
\end{tabular}


Nel [2007] suggested that such inferences are quite questionable for pre-Pleistocene faunas because these fossil midges are extinct species that, in the best case, belong to extant genera but can also correspond to fossil genera.

It was not possible to make inferences from ecological data obtained from the Nearctic and European faunas alone. Nearly all the genera identified in this study live in temperate to cool climates. An inference of a temperate paleoclimate is compatible with all the genera. We refer genera recorded from the Rovno amber to the same type of the larval habitats, which was proposed by Seredszus, and compare our data to those of the Baltic amber [Seredszus \& Wichard, 2007]. Results of the comparison are presented in Table 1 and 2. The present analysis is based on 122 chironomid inclusions identified to generic level (78) or only to subfamily (44 specimens).

Table 2 Ecological preference of the larvae of chironomid midge genera found in Rovno and Baltic amber. Таблица 2. Экологические предпочтения современных личинок хирономид из родов, найденных в ровенском и балтийском янтарях.

\begin{tabular}{|c|c|c|}
\hline Type of habitat & Rovno amber & $\begin{array}{c}\text { Baltic amber (Seredzus, 2003; Seredzus \& } \\
\text { Wichard, 2011, Wichard et al. 2009). }\end{array}$ \\
\hline $\begin{array}{l}\text { Crenobiontic } \\
\text { (spring habitats } \\
\text { only) }\end{array}$ & $\begin{array}{l}\text { Macropelopia (3 spp.) } \\
\text { Metriocnemus (1 sp.) } \\
\text { Orthocladius (1 sp.) } \\
\text { Parachaetocladius }(1 \mathrm{sp} .)\end{array}$ & $\begin{array}{l}\text { Chaetocladius }(1 \mathrm{sp} .) \\
\text { Stempellinella }(1 \mathrm{sp} .) \\
\text { Paraboreochlus }(1 \mathrm{sp} .) \\
\text { Krenosmittia }(1 \mathrm{sp} .) \\
\text { Parachaetocladius }(1 \mathrm{sp} .)\end{array}$ \\
\hline Crenophilous & $\begin{array}{l}\text { Macropelopia (2 spp.) } \\
\text { Metriocnemus ( } 3 \text { spp.) } \\
\text { Parachaetocladius (1 sp.) }\end{array}$ & $\begin{array}{l}\text { Chaetocladius (5 spp.) } \\
\text { Stempellinella (1 sp.) } \\
\text { Paraphaenocladius }(1 \mathrm{sp} .) \\
\text { Parachaetocladius (1 sp.) }\end{array}$ \\
\hline Lotic & $\begin{array}{l}\text { Metriocnemus (2 spp.) } \\
\text { Orthocladius (5 spp.) } \\
\text { Brillia (1 sp.) } \\
\text { Heterotrissocladius (1 sp.) }\end{array}$ & $\begin{array}{l}\text { Prodiamesa (1 sp.) } \\
\text { Apsectrotanypus (1 sp.) } \\
\text { Heterotrissocladius (1 sp.) } \\
\text { Parametriocnemus (2 spp.) } \\
\text { Pseudorthocladius (1 sp.) } \\
\text { Thienemannia (1 sp.) } \\
\text { Zalutschia (?) } \\
\text { Coelotanypus (?) }\end{array}$ \\
\hline Lentic & $\begin{array}{l}\text { Orthocladius ( } 2 \mathrm{sp} .) \\
\text { Cladopelma }(1 \mathrm{sp} .) \\
\text { Heterotrissocladius (1 sp.) }\end{array}$ & $\begin{array}{l}\text { Heterotrissocladius (1 sp.) } \\
\text { Psectrocladius (2 spp.) }\end{array}$ \\
\hline Ubiquitos & $\begin{array}{l}\text { Ablabesmyia (?) } \\
\text { Macropelopia (1 sp.) } \\
\text { Cricotopus }(?) \\
\text { Limnophyes }(2 \mathrm{spp} .) \\
\text { Metriocnemus (1 sp.) } \\
\text { Orthocladius (1 sp.) } \\
\text { Heterotrissocladius (1 sp.) }\end{array}$ & $\begin{array}{l}\text { Prodiamesa (1 sp.) } \\
\text { Procladius (1 sp.) } \\
\text { Lasiodiamesa (1 sp.) } \\
\text { Chaetocladius (2 spp.) } \\
\text { Heterotrissocladius (1 sp.) } \\
\text { Paraphaenocladius (1 sp.) } \\
\text { Pseudorthocladius (1 sp.) } \\
\text { Stempellina (1 sp.) } \\
\end{array}$ \\
\hline Madicolous & $\begin{array}{l}\text { Limnophyes (3 spp.) } \\
\text { Metriocnemus (3 spp.) } \\
\text { Smittia (1 sp.) } \\
\text { Orthocladius (1 sp.) } \\
\text { Hydrosmittia (5 spp.) }\end{array}$ & $\begin{array}{l}\text { Chaetocladius (2 spp.) } \\
\text { Paraphaenocladius (2 spp.) } \\
\text { Pseudorthocladius (1 sp.) }\end{array}$ \\
\hline $\begin{array}{l}\text { Terrestrial and } \\
\text { semiterrestrial }\end{array}$ & $\begin{array}{l}\text { Metriocnemus ( } 2 \text { spp.) } \\
\text { Smittia (almost all species terrestrial except } \\
\text { Smittia contigens (Walker, 1956) }\end{array}$ & $\begin{array}{l}\text { Bryophaenocladius (1 sp.) } \\
\text { Krenosmittia (1 sp.) } \\
\text { Paraphaenocladius (1 sp.) } \\
\text { Pseudorthocladius (1 sp.) }\end{array}$ \\
\hline $\begin{array}{l}\text { Unknown ecolo- } \\
\text { gical preference }\end{array}$ & & Tokyobrillia \\
\hline
\end{tabular}

NOTE. Type of habitats by Lindegaard, 1995. Number of species of each genera in each habitat is given by Lindegaard, 1995; Ferrington \& Saether, 2011. Data relevant for Europe.

ПРИМЕЧАНИЕ: Типы биотопов даны по Lindegaard, 1995. Количество видов в каждом роде, дано по by Lindegaard, 1995; Ferrington \& Saether, 2011: 103. Данные соответствуют европейским видам. 
Table 3 Composition of chironomid subfamilies of the main Eocene and Miocene Lagerstattes of fossil resins Таблица 3. Состав подсемейств комаров-звонцов в основных эоценовых и миоценовых лагерштеттах ископаемых смол.

\begin{tabular}{|c|c|c|c|c|c|c|c|}
\hline Lagerstätte & 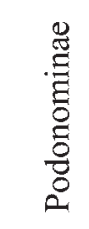 & 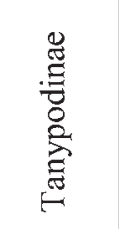 & 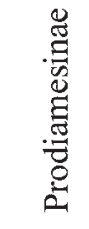 & 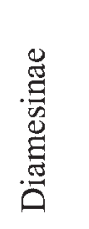 & 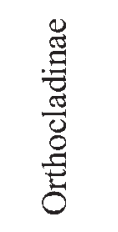 & 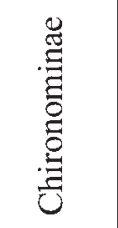 & Specimens \\
\hline Rovno Amber & - & $1.6 \%$ & - & - & $91.8 \%$ & $6.6 \%$ & 122 \\
\hline Baltic Amber* & $>1 \%$ & $1.3 \%$ & $>1 \%$ & - & $91.4 \%$ & $6.5 \%$ & 2216 \\
\hline Oise amber** & - & $14.9 \%$ & $0.4 \%$ & $>1 \%$ & $60.3 \%$ & $23.7 \%$ & 841 \\
\hline Dominican amber*** & - & $12.0 \%$ & - & - & $32.0 \%$ & $56.0 \%$ & 108 \\
\hline Mexican amber*** & - & $9.0 \%$ & - & - & $54.0 \%$ & $27.0 \%$ & 11 \\
\hline
\end{tabular}

NOTE. * - after Seredszus \& Wichard, 2007, Wichard et al. 2009; ** — after Doitteau \& Nel, 2007; *** — after Grund, 2005; **** _ after Solórzano Kraemer, 2007.

ПРИМЕЧАНИЯ. * — по Seredszus \& Wichard, 2007, Wichard et al. 2009; ** — по Doitteau \& Nel, 2007; *** — по Grund, 2005; **** — по Solórzano Kraemer, 2007.

Below we compared the relative (percentage) composition of chironomid subfamilies of the main Eocene and Miocene Lagerstättes of fossil resins (Table 3).

Ashe et al. [1987] indicated that the Chironominae dominate warm tropical areas: "their number rise with decreasing latitude and altitude" whereas "the number of Orthocladiinae rises with increasing latitude and altitude". The general consensus concerning Dominican amber ecosystem is that it was a moist, tropical forest [Penney, 2010]. The most abundant chironomid genera there are Xestochironomus Sublette \& Wirth 1972 with xylophagous larvae and Ablabesmyia \& Polypedilum Kieffer 1913 with predominately limnophilous larvae [Grund, 2005]. The larvae of Xestochironomus are highly specialized wood miners in lotic freshwaters in the Neotropics and in the southern USA. The wood-mining larvae are found in dead submerged angiosperm wood.

The Rovno amber chironomines are not abundant, whereas orthocladiines are strongly dominant. In the Baltic amber orthocladiines are more common than any other group of insects. Baltic amber chironomines are not rare, but 14 times less represented, than orthoclads [Seredszus \& Wichard, 2007]. In general the subfamilial-level composition of Chironomidae in the Baltic and Rovno amber is quite similar (Tabl. 3).

The reason for extremely low number of the genera found in both Lagerstättes (e.g. Parachaetocladius and Heterotrissocladius) is probably because only 45 of 293 preserved males are identified to the generic level in Wichard collection [Seredszus \& Wichard, 2007; Wichard et al., 2009].

Still the high percentage of chironomids with terrestrial larvae in Rovno amber is a major difference: the absence of orthoclads with terrestrial larvae in Baltic amber is mentioned by Seredszus [Seredszus \& Wichard, 2007: 88]. They supposed that they were absent even in genera with some extant species with terrestrial larvae ( $17.8 \%$ of all chironomids, identified to generic level).
Most of Smittia and Limnophyes are easy recognisable, and Seredszus could not have missed them .

The Rovno amber chironomids assemblage demonstrates a high percentage ( $40.3 \%$ of specimens identifiable to generic level - 31 specimens) from genera whose larvae occur in terrestrial or semiterrestrial habitats (Smittia - 23 specimens, Hydrosmittia, Metriocnemus). Limnophyes is the most abundant genus of non-biting midges in the studied sample of Rovno amber (31 specimens - 40.3\%), Smittia is second. The larvae of most Limnophyes species live in moss, wet earth or wet leaves and often hygropetric in springs, streams, seeps or road cuttings.

A few species, however, appear to be truly aquatic, living in the littoral zone of lakes or in small streams [Przhiboro \& Sæther, 2007]. All in all, four mentioned genera account for $80.6 \%$ of all Rovno amber chironomids. In contrast, chironomids with terrestrial larvae are not reported from the other Lagerstättes, except for the very doubtful records from the Upper Cretaceous Canadian amber (Smittia veta, Metriocnemus cretatus) [Boesel, 1937; Veltz et al., 2007].

We are almost certain that Smittia from Rovno ambers had terrestrial larvae, because among 25 species of Smittia found in Europe, only several (Smittia contingens (Walker, 1956)) has truly aquatic larvae [Ashe \& Cranston, 1991]. At the moment, we can suppose that terrestrial and semiterrestrial chironmids were really more abundant in the Rovno amber ecosystems, than in other amber forests. More wide and uniform study of chironomid fossils in both Baltic and Rovno ambers, as well as the analysis of chironomid synclusions [like that provided by Perkovsky et al., 2010], might resolve the problem in future.

ACKNOWLEDGMENTS. Authors wish to express their sincere thanks to Valery Korneyev (I.I. Schmalhausen Institute of Zoology, Kiev) for assistance in taking photos, to Alexandr Rasnitsyn (Paleontological institute, Moscow), 
Trond Andersen and Humberto F. Mendes (University of Bergen, Norway) \& Neal Evenhuis (Bishop Museum, Hawaii, USA) for reading early versions of this manuscript and useful critical comments to text and pictures. We also grateful to Zoya Fedotova (Samara State Agricultural Academy, Ust'Kinel'skii) for providing useful comments to photos \& drawings. Special thanks to Martin Speies (Zoologische Staatssammlung München) \& Patrick Ashe (Dublin) for discussion on some difficult problems of the chironomids zoogeography.

\section{References}

Ashe P., Murray D.A. \& Reiss F. 1987. The zoogeographical distribution of Chironomidae (Insecta: Diptera) // Annales de Limnologie. Vol.23. P.27-60.

Ashe P. \& Cranston P.S. 1991. Family Chironomidae// A. Soós \& L. Papp (eds.). Catalogue of Palaearctic Diptera. Vol.2. Psychodidae-Chironomidae. Amsterdam: Elsevier Science Publishers. P.113-355.

Boesel M.W. 1937. Diptera // F.M. Carpenter, J.W. Folsom, E.O. Essig, A.C. Kinsey, C.T. Brues, M.W. Boesel \& H.E. Ewing (eds.). Insects and Arachnids from Canadian Amber, Chironomidae. University of Toronto Studies, Geology Series. Vol.40. P.44-55.

Cranston P.S., Dillon M.E., Pinder L.C. \& Reiss F. 1989. The adult males of Chironominae (Diptera: Chironomidae) of the Holarctic region - runs and diagnoses // T. Wiederholm (ed.). Chironomidae of the Holarctic region. Runs and diagnoses. Pt.3. Adult males. Entomologica Scandinavica. Supplement. Vol.34. P.353-502.

Cranston P.S., Oliver D.R. \& Sæther O.A. 1989. The adult males of Orthocladiinae (Diptera: Chironomidae) of the Holarctic regionruns and diagnoses // T. Wiederholm (ed.). Chironomidae of the Holarctic region. Runs and diagnoses. Pt.3. Adult males // Entomologica Scandinavica. Supplement. Vol.34. P.165-352.

Doitteau G. \& Nel A. 2007. Chironomid midges from early Eocene amber of France (Diptera: Chironomidae) // Zootaxa. Vol.1404. P.1-66.

Evenhuis N.L. 1994. Catalogue of the fossil flies of the World (Insecta: Diptera). Leiden: Backhuys Publishers. P.1-600

Ferrington L. 2007 Global diversity of non-biting midges Chironomidae; Insecta-Diptera) in freshwater// Hydrobiologia. Vol.595. P.447-455.

Ferrington L. \& Sæther O.A. 2011. A revision of the genera Pseudosmittia Edwards, 1932, Allocladius Kieffer, 1913, and Hydrosmittia gen.n. (Diptera: Chironomidae, Orthocladiinae) // Zootaxa. Vol.2849. P.1-314.

Gilka W. 2010. A new species group in the genus Tanytarsus van der Wulp (Diptera: Chironomidae) based on a Fossil Record on Baltic Amber// Acta Geologica Sinica. Vol 84. No.4. P. 714719.

Gilka W. 2011. A new fossil Tanytarsus from Eocene Baltic amber, with notes on systematics of the genus (Diptera: Chironomidae) // Zootaxa. Vol. 3069. P. 63-68.
Grund M. 2005. Chironomidae (Diptera) in Dominican amber as indicators for ecosystem stability in the Caribbean // Palaeogeography, Palaeoclimatology, Palaeoecology. Vol.241. P.410416.

Lindegaard C. 1995. Chironomidae (Diptera) of European Cold Springs and Factors Influencing Their Distribution // Biodiversity of Aquatic Insects and Other Invertebrates in Springs. Vol.1. P.108-131.

Meunier F. 1904. Monographie des Cecidomyiidae, Sciaridae, Mycetophilidae et Chironomidae de l'ambre de la Baltique // Annales de la Société Scientifique de Bruxelles. Vol.28 P.13-276.

Makarchenko E. A. \& Makarchenko M.A. 2007. Subfamily Orthocladiinae // A.S. Lelei (ed.) Key to the insects of Russian Far East. Vol.6. Diptera and Siphonaptera (2006). Pt.4. Vladivostok: Dal'nauka. P.280-671 [in Russian, with English abstract].

Moller Pillot K.M.H. 2008. Identification and ecology of the genus Smittia Holmgren in the Netherlands (Diptera: Chironomidae) // Tijdschrift voor Entomologie. Vol.151. P.245-270.

Murray D.A. \& Fittkau E.J. 1989. The adult males of Tanypodinae (Diptera: Chironomidae) of the Holarctic region -runs and diagnoses // T. Wiederholm (ed.). Chironomidae of the Holarctic region. Runs and diagnoses. Pt.3. Adult males. Entomologica Scandinavica. Supplement. Vol.34. P.37-123

Penney D. 2010. Dominican Amber // Biodiversity of fossils in amber: from the major world deposit. David Penney. P.22-41.

Perkovsky E. E., Zosimovich V.Yu. \& Vlaskin A.P. 2003. Rovno amber insects: first results of analysis // Russian Entomological Journal. Vol.12. No.2. P.119-126.

Perkovsky E.E., Zosimovich V.Yu. \& Vlaskin A.P. 2010. Rovno Amber // Biodiversity of fossils in amber: from the major world deposit. David Penney. P.116-136.

Przhiboro A. \& Sæther O.A. 2007. Limnophyes (Diptera: Chironomidae) from northwestern Russia // Aquatic Insects. Vol.29. No.1. P.49-58.

Sæther O.A. 1980. Glossary of chironomid morphology terminology (Chironomidae, Diptera) // Entomologica scandinavica. Supplement. Vol.14. P.1-51.

Sæther O.A., Ashe P. \& Murray D.A. 2000. Family Chironomidae // L. Papp, B. Darvas (eds.). Contributions to a Manual of Palaearctic Diptera (with special reference to the flies of economic importance). Vol.4. A.6. Budapest: Science Herald. P.113-334.

Seredszus F. \& Wichard W. 2007. Fossil chironomids (Insecta; Diptera) in Baltic amber // Paleontographica. Vol.279. P.41-91.

Seredszus F. \& Wichard W. 2011. Overview and descriptions of fossil non-biting midges in Baltic amber (Diptera: Chironomidae) // Studia dipterologica. Vol.17. P.121-129.

Solórzano Kraemer M.M. 2007. Systematic, paleoecology and paleobigeography of the insect fauna, from Mexican amber // Paleontographica. Vol.282. P.1-133.

Veltz I., Azar D. \& Nel A., 2007. New chironomid flies in theEarly Cretaceous Lebanese amber (Diptera: Chironomidae) // African Invertebrates. Vol.48. No.1. P.169-191.

Wichard W., Gröhn C.\& Seredszus F. 2009. Aquatic Insects in Baltic Amber. Wasserinsecten im Baltischen Bernstein. RemagenOberwinter: Verlag Kessel.335 p. 